\title{
PROSTHETIC REPLACEMENT OF THE DISTAL FEMUR FOR PRIMARY BONE TUMOURS
}

\author{
P. ROBERTS, D. CHAN, R. J. GRIMER, R. S. SNEATH, J. T. SCALES
}

From the Bone Tumour Treatment Service, Royal Orthopaedic Hospital, Birmingham

Over a 16-year period, 135 custom-made distal femoral prostheses, based on a fully constrained Stanmore-type knee replacement, were used in the treatment of primary malignant or aggressive benign tumours.

Survivorship analysis showed a cumulative success rate of $72 \%$ at five years and $64 \%$ at seven years. Intact prostheses in $\mathbf{9 1 \%}$ of the surviving patients gave good or excellent functional results. Deep infection was the major complication, occurring in $6.8 \%$ of cases; clinical aseptic loosening occurred in $6.0 \%$. Revision surgery was carried out for loosening and infection, and the early results are encouraging.

We conclude that prosthetic replacement of the distal femur can meet the objectives of limb salvage surgery.

Limb salvage surgery for malignant bone tumours has become accepted practice due largely to the improvement in tumour control with modern chemotherapy (Rosen et al 1983; Link et al 1986; Simon and Nachman 1986; Eilber et al 1987), and also to progress in surgical reconstruction. The most commonly used replacements are allografts and prostheses. The latter have the advantage of being readily available, can be made to measure for the individual patient and are not prone to resorption. Limb salvage surgery should improve the quality of life compared to amputation, but it must not jeopardise survival. Recent studies have shown that limb salvage surgery offers the same prospect of survival as amputation although there is a small increase in risk of local recurrence (Marcove and Rosen 1980; Eilber et al 1984; Simon et al 1986; Springfield et al 1988).

In the United Kingdom, prostheses were first used following major long bone resection at the Royal National Orthopaedic Hospital, Stanmore (Seddon and Scales

P. Roberts, MA, FRCS, Research Registrar

D. Chan, FRCS Ed, Orthopaedic Registrar

R. J. Grimer, FRCS, FRCS Ed(Orth), Consultant Orthopaedic Oncologist

R. S. Sneath, FRCS, Director

Bone Tumour Treatment Service, Royal Orthopaedic Hospital, Northfield, Birmingham B31 2AP, England.

J. T. Scales, $O B E$, FRCS, CIMechE, Honorary Director of Research in Plastic Surgery

Mount Vernon Hospital, Northwood, Middlesex, England.

Correspondence should be sent to Mr P. Roberts.

(C) 1991 British Editorial Society of Bone and Joint Surgery $0301-620 X / 91 / 5168 \$ 2.00$

J Bone Joint Surg [Br] 1991; 73-B: 762-9.

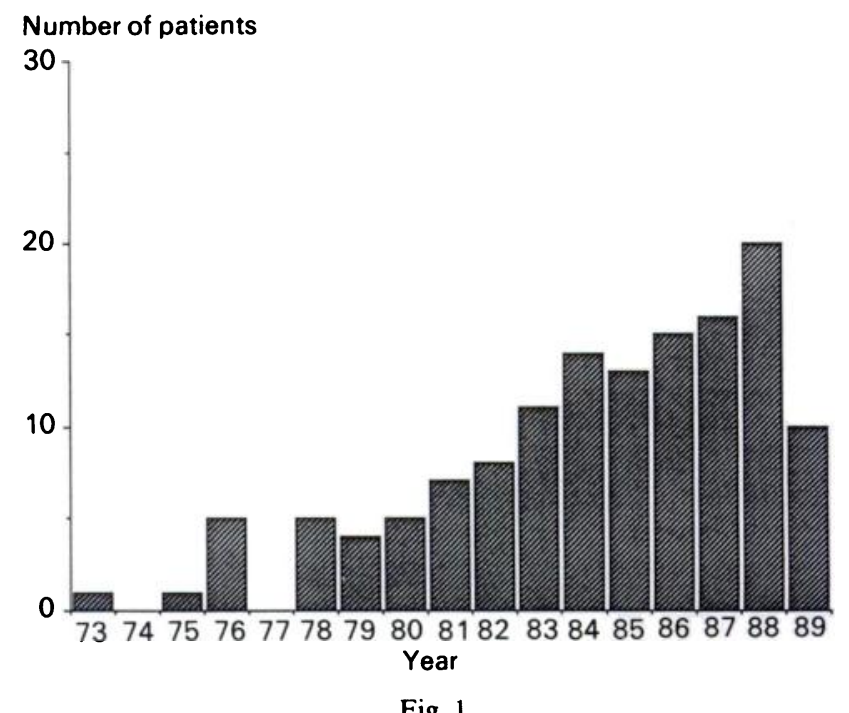

Fig. 1

The number (135) of distal femoral replacements carried out for primary malignant or aggressive benign bone tumours at the Royal Orthopaedic Hospital, Birmingham, between 1973 and June 301989.

1949), and subsequent work was reported by Burrows, Wilson and Scales (1975).

Prostheses have been used by the Birmingham Bone Tumour Treatment Service to replace defects in major long bones since 1973. The distal femur is the most common site for osteosarcoma. The use of distal femoral prostheses has been reported by Bradish et al (1987), who reviewed a small number of patients with mainly nonmalignant conditions.

Durability of the implanted prosthesis and its fixation in bone has always been the major concern of 
limb-salvage surgery. We report on 16 years experience with prosthetic replacements of the distal femur for primary bone tumours.

\section{PATIENTS AND METHODS}

Between December 1973 and July 1989, 135 skeletally mature patients underwent prosthetic replacement of the distal femur for malignant or aggressive benign primary bone tumours. The number performed each year has been increasing rapidly (Fig. 1) due in part to an increase in the number of referrals and in part to a widening of the indications for limb salvage surgery. The diagnosis of each case is shown in Table I, $63 \%$ of patients had a high grade osteosarcoma. In $8 \%$ of cases surgery was carried out for a relatively benign condition, aggressive recurrent giant-cell tumour.

Table I. Diagnosis and number of patients surviving to date

\begin{tabular}{lll}
\hline Diagnosis & Number & Surviving \\
\hline Osteosarcoma & 86 & 63 \\
Chondrosarcoma & 11 & 11 \\
$\begin{array}{l}\text { Malignant fibrous } \\
\text { histiocytoma }\end{array}$ & 11 & 7 \\
Giant cell tumour & 11 & 9 \\
Fibrosarcoma & 8 & 4 \\
Others & 8 & 5 \\
\hline
\end{tabular}

The median age of the patients was 22 years (Fig. 2). The most common tumour was osteosarcoma, which explains the large number of adolescents and young adults. Patients who were skeletally immature were excluded from this study.

Pre-operatively all patients were 'staged' using conventional radiography, scintigraphy and computerised axial tomography of the lesion and lungs. An open biopsy of every lesion was carried out. Clearance biopsies were also taken from the femur at the planned site of resection to confirm the absence of tumour. Sensitivity to metallic elements and alloys used in the prosthesis was investigated by a skin patch technique. Pre-operative and postoperative chemotherapy was given on the basis of the histological diagnosis and the relevant chemotherapy trial in which the unit was involved. Before definitive surgery was undertaken most of the patients were restaged and all gave consent to amputation should limb salvage prove impossible to carry out safely.

The prostheses were designed and manufactured according to measurement radiographs of each patient, by the Department of Biomedical Engineering of the Institute of Orthopaedics at the Royal National Ortho- paedic Hospital. A Stanmore-type knee was used, made either of vacuum cast, vacuum melt, cobalt chromium molybdenum alloy (Biomet, Swindon, UK; BS 3531, Part 2,1980 , and ISO $5832 / \mathrm{IV}, 1978 \mathrm{E}$ ) or if the patient gave a positive patch test to elements contained in this alloy, of commercially pure titanium type T5 (IMI (Titanium), Birmingham, UK ; BS 3531, Part 2, 1980, and ISO 5832/ II, 1978) or titanium alloy containing $6 \%$ aluminium and $4 \%$ vanadium (IMI (Titanium), Birmingham, UK; BS 3531, Part 2, 1980, ISO 5832/III, 1978). The bushes in the femoral component were made of ultra-high molecular weight polyethylene (RCH 1000 (R), Ruhrchemie AG, Oberhausen-Holten, Germany). The knee axle was either of cobalt chromium molybdenum alloy or of

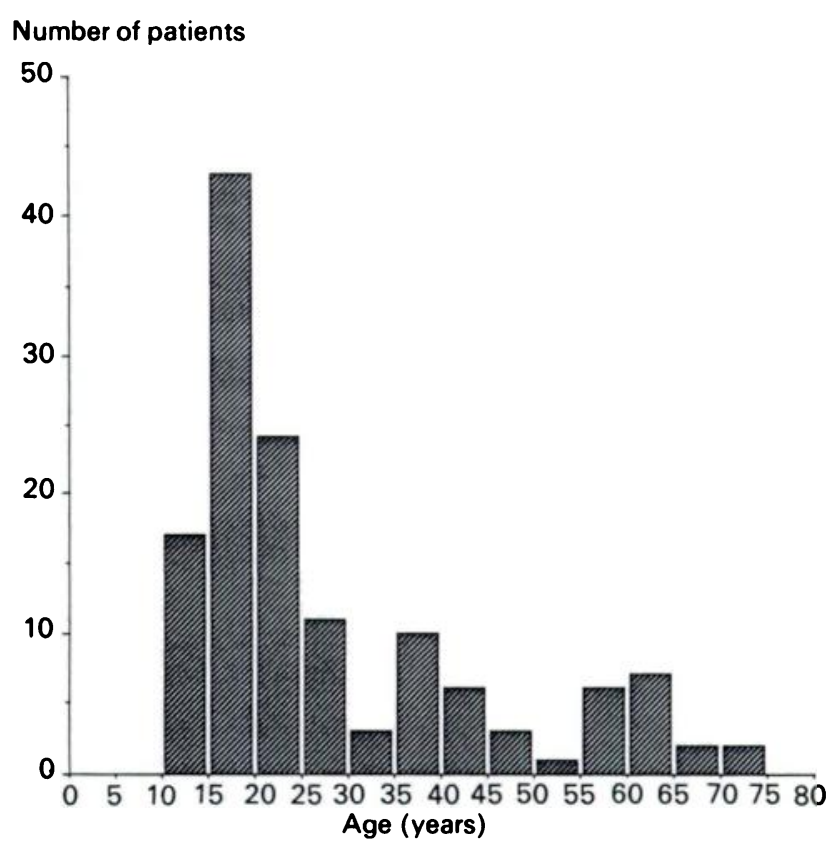

Fig. 2

The age distribution of patients undergoing distal femoral replacement.

commercially pure titanium, coated with aluminium oxide using a detonation gun technique (Union Carbide, Swindon, UK). The axle was retained by a titanium alloy (TAl) circlip. Plateau plates of titanium alloy type TAl were used only with the cobalt chromium molybdenum alloy tibial components, which were not custom made.

The proportion of the femoral shaft excised in the 135 patients varied between $25 \%$ and $75 \%$. To prevent torsion the intramedullary stems had either a medial or lateral flat, or else three equally spaced flutes. Each stem was contoured to correspond with the anteroposterior curve of the remaining intramedullary cavity of the bone. All stems, which varied in length from 50 to $160 \mathrm{~mm}$, were grouted into the intramedullary cavity using Simplex acrylic bone cement (Howmedica International, London, UK) usually introduced with a cement gun. An example 
of a custom-made distal femur and knee prosthesis is shown in Figure 3.

The tumour resection was carried out following oncological principles with a wide margin of resection, as defined by Enneking, Spanier and Goodman (1980). Prophylactic parenteral antibiotics were used during surgery. All the operations were carried out by one of two surgeons (RSS, RJG).

After the operation patients were mobilised gently, bearing partial weight when the drains were removed. Most patients left hospital walking with the aid of sticks within two weeks; six weeks following surgery all patients returned for a period of intensive in-patient physiotherapy, during which a good range of movement was achieved and walking aids discarded. The patients were seen at three-monthly intervals for the first two years, at six-monthly intervals for a further three years and yearly thereafter. All patients who attended clinic during the last nine months had their level of function assessed according to Enneking's method (1987). The scoring system is shown in Table II.

\section{RESULTS}

A single patient died during surgery, a second was lost to follow-up in the first three months after surgery, leaving 133 available for study. The follow-up period was defined as the time from surgery to the date last seen for asymptomatic patients, or the date of death, amputation, revision surgery, or development of significant symptoms if they occurred. The median follow-up was 34 months and the longest was 156 months. The distribution is shown in Figure 4; 34 patients have been followed up for more than five years.

Survivorship analysis. Survivorship has been calculated by Armitage's method (1971) as recommended by Tew and Waugh (1982). Actuarial survival tables were constructed using three criteria of success:

1) Avoidance of amputation - 13 failures (Table III). One amputation was performed a few days after operation because of critical ischaemia in a leg which had severe post-irradiation fibrosis. Ten amputations were carried out for local recurrence of tumour. Two amputations were performed later for persistent infection;

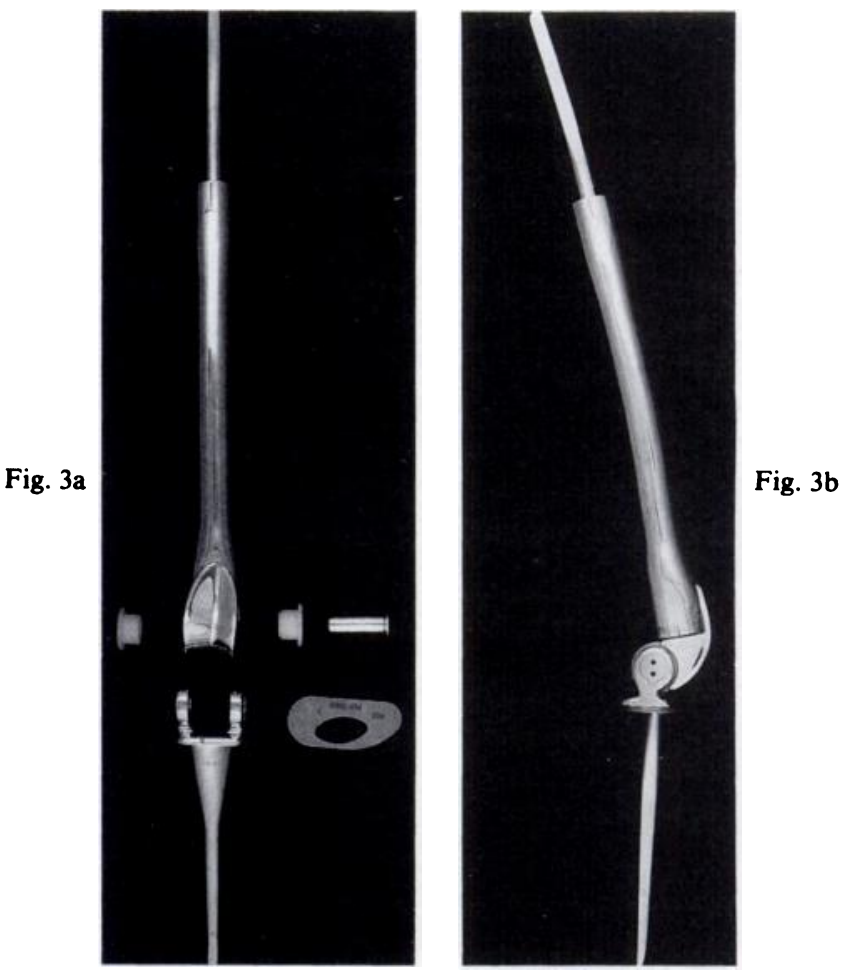

An example of a custom made distal femur and knee prosthesis.

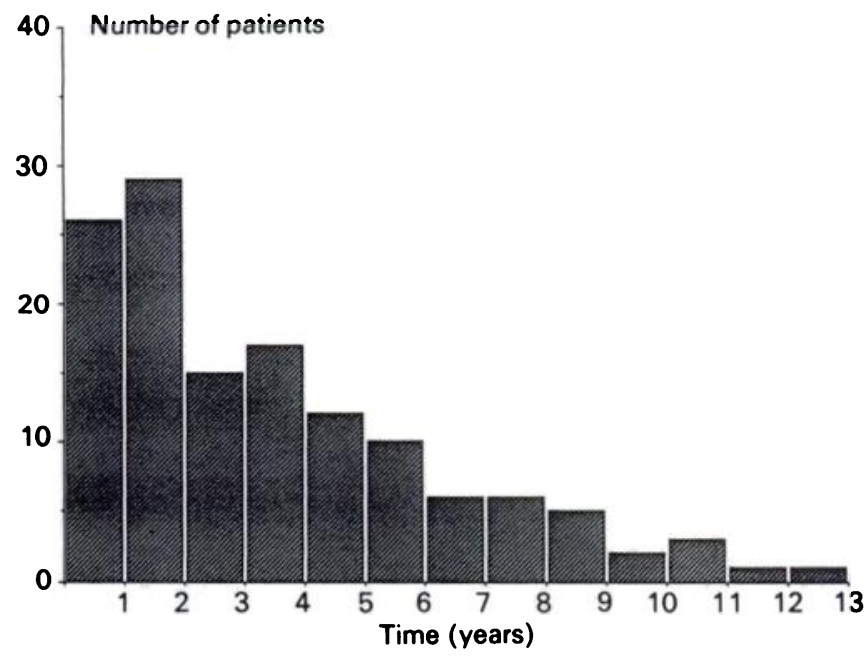

Fig. 4

The length of follow-up, time to amputation, revision or onset of symptoms of failure (infection or loosening).

Table II. Functional assessment of patients following surgery

\begin{tabular}{|c|c|c|c|c|c|c|c|c|c|c|c|}
\hline \multirow[b]{2}{*}{ Grade } & \multirow[b]{2}{*}{ Score } & \multirow[b]{2}{*}{$\begin{array}{l}\text { Knee } \\
\text { flexion }\end{array}$} & \multirow[b]{2}{*}{ Pain } & \multicolumn{2}{|l|}{ Stability } & \multicolumn{3}{|l|}{ Deformity } & \multirow[b]{2}{*}{$\begin{array}{l}\text { Strength } \\
\text { (MRC) }\end{array}$} & \multirow[b]{2}{*}{$\begin{array}{l}\text { Functional } \\
\text { activity }\end{array}$} & \multirow[b]{2}{*}{$\begin{array}{l}\text { Subjective } \\
\text { opinion }\end{array}$} \\
\hline & & & & $\mathbf{V} / \mathbf{V}^{*}$ & $\begin{array}{l}\text { Giving } \\
\text { way }\end{array}$ & $\mathbf{v} / \mathbf{v}^{*}$ & $\begin{array}{l}\text { Flex } \\
\text { cont. }\end{array}$ & $\begin{array}{l}\text { Shortening } \\
\text { (cm) }\end{array}$ & & & \\
\hline Excellent & 5 & $>90^{\circ}$ & None & $0^{\circ}$ to $5^{\circ}$ & None & $0^{\circ}$ to $5^{\circ}$ & $0^{\circ}$ to $5^{\circ}$ & None & 5 & No restrictions & Delighted \\
\hline Good & 3 & $60^{\circ}$ to $90^{\circ}$ & Modest & $5^{\circ}$ to $10^{\circ}$ & None & $5^{\circ}$ to $10^{\circ}$ & $0^{\circ}$ to $5^{\circ}$ & $<1$ & 4 & $\begin{array}{l}\text { Recreational } \\
\text { restrictions only }\end{array}$ & Satisfied \\
\hline Fair & 1 & $30^{\circ}$ to $60^{\circ}$ & Moderate & $10^{\circ}$ to $20^{\circ}$ & Occasional & $10^{\circ}$ to $20^{\circ}$ & $10^{\circ}$ to $20^{\circ}$ & 1 to 3 & 3 & Partial disability & Acceptable \\
\hline Poor & 0 & $0^{\circ}$ to $30^{\circ}$ & Severe & $>20^{\circ}$ & Habitual & $10^{\circ}$ to $20^{\circ}$ & $>20^{\circ}$ & $>3$ Amp $\ddagger$ & $2,1,0$ & Total disability & Disliked \\
\hline
\end{tabular}

*varus/valgus fflexion contracture łamputee 
Table III. Survivorship table, when success is defined as a patient's limb not being amputated

\begin{tabular}{|c|c|c|c|c|c|c|c|}
\hline \multirow{2}{*}{$\begin{array}{l}\text { Months since } \\
\text { operation }\end{array}$} & \multirow{2}{*}{$\begin{array}{l}\text { Number } \\
\text { at start }\end{array}$} & \multicolumn{2}{|c|}{ Result at last review } & \multirow{2}{*}{$\begin{array}{l}\text { Number } \\
\text { at risk }\end{array}$} & \multirow{2}{*}{$\begin{array}{l}\text { Failure rate } \\
\text { (per cent) }\end{array}$} & \multirow{2}{*}{$\begin{array}{l}\text { Success rate } \\
\text { (per cent) }\end{array}$} & \multirow{2}{*}{$\begin{array}{l}\text { Cumulative } \\
\text { success rate } \\
\text { (per cent) }\end{array}$} \\
\hline & & Success & Failure & & & & \\
\hline 0 to 60 & 133 & 7 & 1 & 129.5 & 0.8 & 99.2 & 99.2 \\
\hline 6 to 12 & 125 & 11 & 7 & 119.5 & 5.9 & 94.1 & 93.4 \\
\hline 12 to 18 & 107 & 13 & 1 & 100.5 & 1.0 & 99.0 & 92.5 \\
\hline 18 to 24 & 93 & 14 & 1 & 86.0 & 1.2 & 98.8 & 91.4 \\
\hline 24 to 30 & 78 & 5 & 1 & 75.5 & 1.3 & 98.7 & 90.2 \\
\hline 30 to 36 & 72 & 9 & 0 & 67.5 & 0.0 & 100.0 & 90.2 \\
\hline 36 to 42 & 63 & 7 & 0 & 69.5 & 0.0 & 100.0 & 90.2 \\
\hline 42 to 48 & 56 & 9 & 1 & 51.5 & 1.9 & 98.1 & 88.5 \\
\hline 48 to 54 & 46 & 4 & 0 & 44.0 & 0.0 & 100.0 & 88.5 \\
\hline 54 to 60 & 42 & 8 & 0 & 38.0 & 0.0 & 100.0 & 88.5 \\
\hline 60 to 66 & 34 & 6 & 0 & 31.0 & 0.0 & 100.0 & 88.5 \\
\hline 66 to 72 & 28 & 3 & 1 & 26.5 & 3.8 & 96.2 & 85.1 \\
\hline 72 to 78 & 24 & 4 & 0 & 22.0 & 0.0 & 100.0 & 1 \\
\hline 78 to 84 & 20 & 2 & 0 & 19.0 & & & \\
\hline 84 to 90 & 18 & 5 & 0 & 15.5 & & 1 & \\
\hline 90 to 96 & 13 & 1 & 0 & 12.5 & & & \\
\hline 96 to 102 & 12 & 4 & 0 & 10.0 & & & \\
\hline 102 to 108 & 8 & 1 & 0 & 7.5 & & & \\
\hline 108 to 114 & 7 & 0 & 0 & 7.0 & & & \\
\hline 114 to 120 & 7 & 2 & 0 & 6.0 & & & \\
\hline 120 to 126 & 5 & 5 & 0 & 2.5 & $\downarrow$ & $\downarrow$ & $\downarrow$ \\
\hline
\end{tabular}

Table IV. Survivorship table, when success is defined as the original prosthesis remaining in situ

\begin{tabular}{|c|c|c|c|c|c|c|c|}
\hline \multirow{2}{*}{$\begin{array}{l}\text { Months since } \\
\text { operation }\end{array}$} & \multirow{2}{*}{$\begin{array}{l}\text { Number } \\
\text { at start }\end{array}$} & \multicolumn{2}{|c|}{ Result at last review } & \multirow{2}{*}{$\begin{array}{l}\text { Number } \\
\text { at risk }\end{array}$} & \multirow{2}{*}{$\begin{array}{l}\text { Failure rate } \\
\text { (per cent) }\end{array}$} & \multirow{2}{*}{$\begin{array}{l}\text { Success rate } \\
\text { (per cent) }\end{array}$} & \multirow{2}{*}{$\begin{array}{l}\text { Cumulative } \\
\text { success rate } \\
\text { (per cent) }\end{array}$} \\
\hline & & Success & Failure & & & & \\
\hline 0 to 6 & 133 & 7 & 1 & 129.5 & 0.8 & 99.2 & 99.2 \\
\hline 6 to 12 & 125 & 11 & 7 & 119.5 & 5.9 & 94.1 & 93.4 \\
\hline 12 to 18 & 107 & 12 & 2 & 101.5 & 2.0 & 98.0 & 91.6 \\
\hline 18 to 24 & 93 & 14 & $\overline{1}$ & 86.0 & 1.2 & 98.8 & 90.5 \\
\hline 24 to 30 & 78 & 4 & 2 & 76.0 & 2.6 & 97.4 & 88.1 \\
\hline 30 to 36 & 72 & 8 & 1 & 68.0 & 1.5 & 98.5 & 86.8 \\
\hline 36 to 42 & 63 & 6 & 1 & 60.0 & 1.7 & 98.3 & 85.4 \\
\hline 42 to 48 & 56 & 7 & 3 & 52.5 & 5.7 & 94.3 & 80.5 \\
\hline 48 to 54 & 46 & 2 & 2 & 45.0 & 4.4 & 95.6 & 76.9 \\
\hline 54 to 60 & 42 & 7 & 1 & 38.5 & 2.6 & 97.4 & 74.9 \\
\hline 60 to 66 & 34 & 5 & 1 & 31.5 & 3.2 & 96.8 & 72.5 \\
\hline 66 to 72 & 28 & 2 & 2 & 27.0 & 7.4 & 92.6 & 67.2 \\
\hline 72 to 78 & 24 & 4 & 0 & 22.0 & 0.0 & 100.0 & 67.2 \\
\hline 78 to 84 & 20 & 2 & 0 & 19.0 & 0.0 & 100.0 & 67.2 \\
\hline 84 to 90 & 18 & 3 & 2 & 16.5 & 12.1 & 87.9 & 59.0 \\
\hline 90 to 96 & 13 & 1 & 0 & 12.5 & 0.0 & 100.0 & \\
\hline 96 to 102 & 12 & 4 & 0 & 10.0 & & 1 & \\
\hline 102 to 108 & 8 & 1 & 0 & 7.5 & & & \\
\hline 108 to 114 & 7 & 0 & 0 & 7.0 & & & \\
\hline 114 to 120 & 7 & 2 & 0 & 6.0 & & & \\
\hline 120 to 126 & 5 & 5 & 0 & 2.5 & & $\downarrow$ & \\
\hline
\end{tabular}

Table V. Survivorship table, when success is defined as a patient who has required no further surgery and has no symptoms

\begin{tabular}{|c|c|c|c|c|c|c|c|}
\hline \multirow{2}{*}{$\begin{array}{l}\text { Months since } \\
\text { operation }\end{array}$} & \multirow{2}{*}{$\begin{array}{l}\text { Number } \\
\text { at start }\end{array}$} & \multicolumn{2}{|c|}{ Result at last review } & \multirow{2}{*}{$\begin{array}{l}\text { Number } \\
\text { at risk }\end{array}$} & \multirow{2}{*}{$\begin{array}{l}\text { Failure rate } \\
\text { (per cent) }\end{array}$} & \multirow{2}{*}{$\begin{array}{l}\text { Success rate } \\
\text { (per cent) }\end{array}$} & \multirow{2}{*}{$\begin{array}{l}\text { Cumulative } \\
\text { success rate } \\
\text { (per cent) }\end{array}$} \\
\hline & & Success & Failure & & & & \\
\hline 0 to 6 & 133 & 7 & 1 & 129.5 & 0.8 & 99.2 & 99.2 \\
\hline 6 to 12 & 125 & 10 & 8 & 120.0 & 6.8 & 93.3 & 92.6 \\
\hline 12 to 18 & 107 & 11 & 3 & 101.5 & 3.0 & 97.0 & 89.9 \\
\hline 18 to 24 & 93 & 14 & 1 & 86.0 & 1.2 & 98.8 & 88.8 \\
\hline 24 to 30 & 78 & 4 & 2 & 76.0 & 2.6 & 97.3 & 86.5 \\
\hline 30 to 36 & 72 & 8 & 1 & 68.0 & 1.5 & 98.5 & 85.2 \\
\hline 36 to 42 & 63 & 6 & 1 & 60.0 & 1.7 & 98.3 & 83.8 \\
\hline 42 to 48 & 56 & 7 & 3 & 52.5 & 5.7 & 94.3 & 79.0 \\
\hline 48 to 54 & 46 & 2 & 2 & 45.5 & 4.4 & 95.6 & 75.5 \\
\hline 54 to 60 & 42 & 6 & 2 & 39.0 & 5.1 & 94.9 & 71.6 \\
\hline 60 to 66 & 34 & 5 & 1 & 31.5 & 3.2 & 96.8 & 69.4 \\
\hline 66 to 72 & 28 & 2 & 2 & 27.0 & 7.4 & 92.6 & 64.2 \\
\hline 72 to 78 & 24 & 4 & 0 & 22.0 & 0.0 & 100.0 & 64.2 \\
\hline 78 to 84 & 20 & 2 & 0 & 19.0 & 0.0 & 100.0 & 64.2 \\
\hline 84 to 90 & 18 & 3 & 2 & 16.5 & 12.1 & 87.9 & 56.4 \\
\hline 90 to 96 & 13 & 1 & 0 & 12.5 & 0.0 & 100.0 & 56.4 \\
\hline 96 to 102 & 12 & 4 & 0 & 10.0 & 0.0 & 100.0 & 56.4 \\
\hline 102 to 108 & 8 & 1 & 0 & 7.5 & 0.0 & 100.0 & 56.4 \\
\hline 108 to 114 & 7 & 0 & 0 & 7.0 & 0.0 & 100.0 & 56.4 \\
\hline 114 to 120 & 7 & 1 & 1 & 6.5 & 15.4 & 84.6 & 47.8 \\
\hline 120 to 126 & 5 & 5 & 0 & 2.5 & 0.0 & 100.0 & 47.8 \\
\hline
\end{tabular}


2) Retention of the original prosthesis - 13 failures (Table IV). Five patients required revision surgery for infection, six for loosening and two for fractured stems;

3) Freedom from symptoms - four failures (Table V). Two patients had painful loosening and await revision. Two patients had proven infection, one of whom died before revision, and the other is on long-term antibiotics.

The Kaplan-Meier survival curves for the three definitions of success are shown in Figure 5. As recommended by Altman et al (1989), the curves have not been taken beyond the time when less than five patients have been followed up. The $95 \%$ confidence intervals, calculated by the method of Machin and Gardner (1988) are shown on each curve for 30, 60 and 90 months follow-up. An important feature of this method of survivorship analysis is illustrated; because the patients have entered the study at different times the number being followed up falls, as the review period increases. This causes the confidence intervals to widen with longer follow-up time. The cumulative survival figure must therefore be interpreted with caution when the number of patients being followed up has fallen to low levels.

Nevertheless it can be seen that if a primary bone tumour of the distal femur is treated by resection and prosthetic replacement, there is an $88 \%$ likelihood $(95 \%$ confidence interval 79 to 98 ) that, at five years, the patient will not have required amputation. Likewise, at five years there is a $75 \%$ likelihood $(95 \%$ confidence interval 62 to 88) that the original prosthesis will be in situ and there is a $72 \%$ chance $(95 \%$ confidence interval 59 to 85 ) that it will be asymptomatic.

Functional assessment. This was carried out on 71 of the 99 surviving patients. The results are shown in Table VI and the total scores shown in Figure 6. Most patients were rated good or excellent for each parameter of assessment and $91 \%$ were good or excellent overall. Poor scores were usually associated with infection at the time

Table VI. Results of functional assessment

\begin{tabular}{lllllllll}
\hline & Motion & Pain & Stability & Deformity & Strength & $\begin{array}{l}\text { Functional } \\
\text { activity }\end{array}$ & $\begin{array}{l}\text { Subjective } \\
\text { opinion }\end{array}$ & $\begin{array}{l}\text { Overall } \\
\text { grade }\end{array}$ \\
\hline Excellent & 57 & 49 & 64 & 65 & 47 & 27 & 43 & 28 \\
Good & 11 & 21 & 1 & 3 & 20 & 35 & 24 & 37 \\
Fair & 2 & 1 & 5 & 3 & 2 & 9 & 4 & 4 \\
Poor & 1 & 0 & 1 & 0 & 2 & 0 & 0 & 2 \\
\hline
\end{tabular}

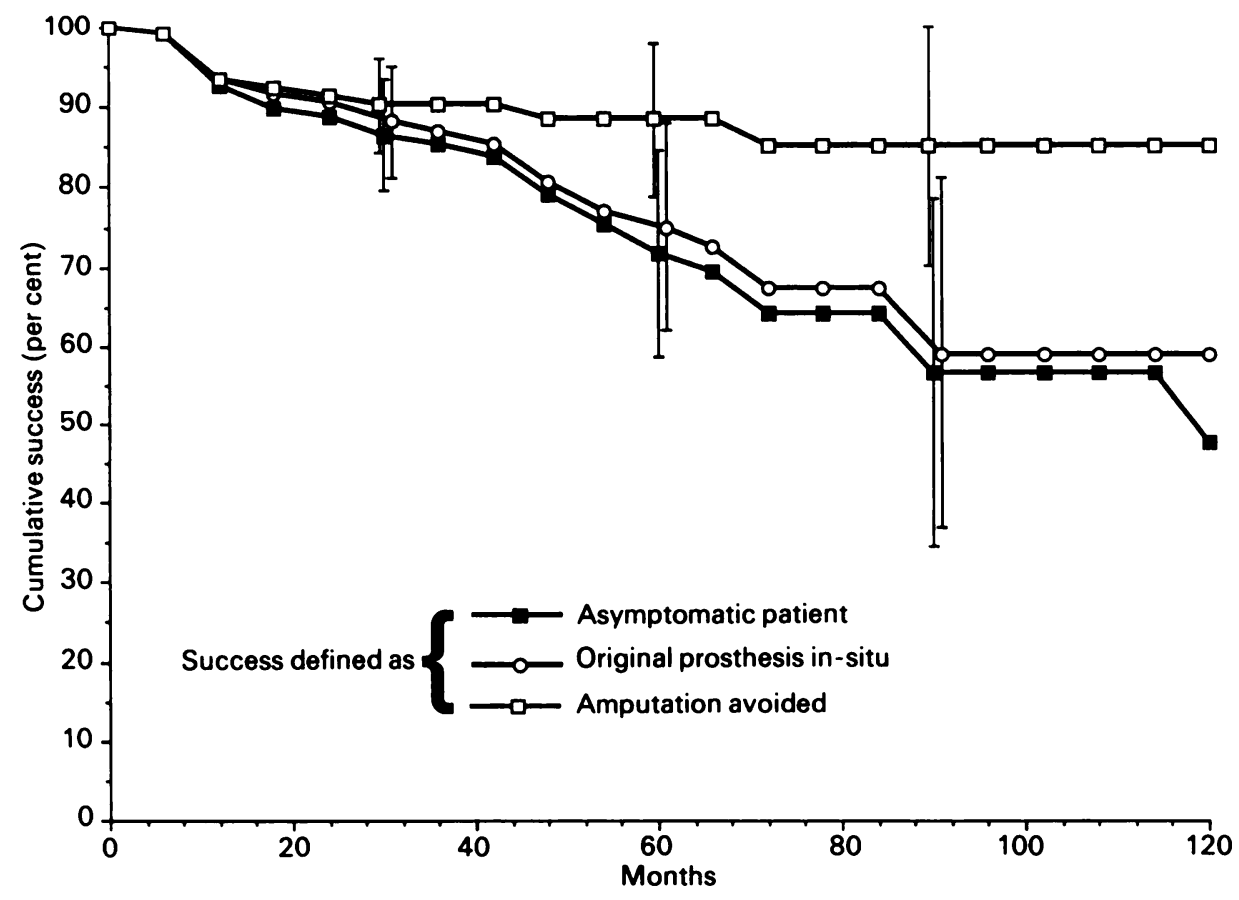

Fig. 5

Kaplan-Meier survival curves for three definitions of success. Confidence intervals of $95 \%$ shown for 30 , 60 and 90 months. 


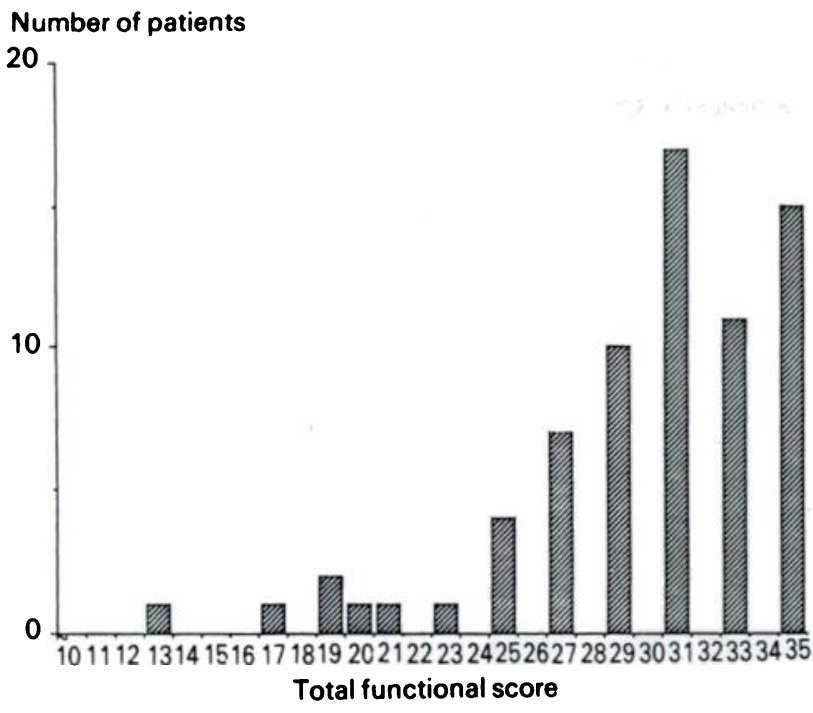

Fig. 6

Total functional score (median $=31)$ of each patient $(n=71)$ after primary surgery.

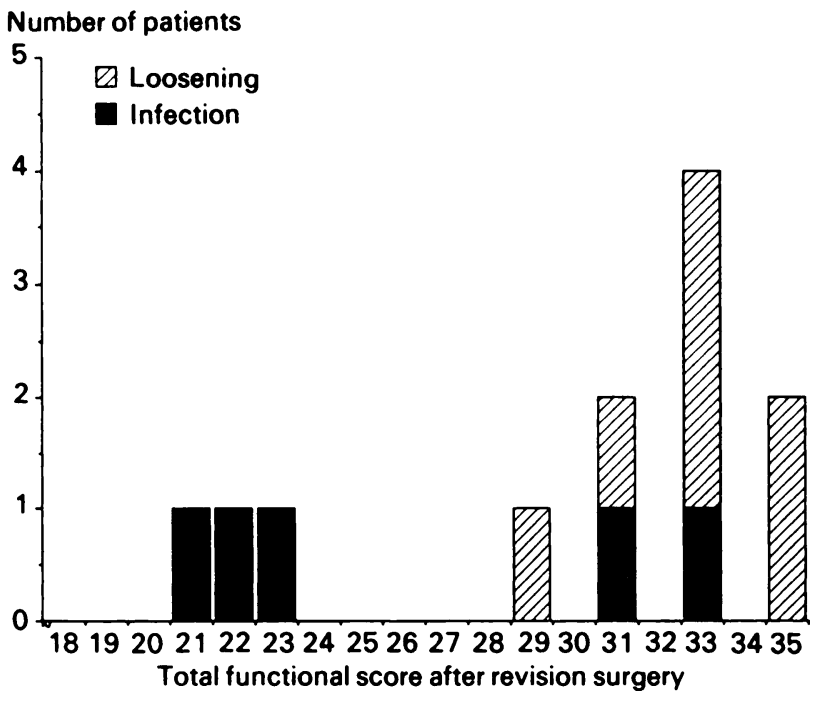

Fig. 7

Total functional score after revision surgery in 12 patients.

of assessment. Only four patients were unhappy with the overall result and no patient was so unhappy that they would have preferred amputation.

Revision surgery. There were 13 patients who required revision surgery, five for infection, six for loosening and two for prosthetic fracture. The time interval since revision is short (mean 17 months, range 4 to 40 ); one patient has required a second revision for persistent infection but the other 12 remain asymptomatic. The functional result was excellent when revision was carried out for loosening, but not so good when carried out for infection (Fig. 7).

Infection. This has been the major complication requiring surgical intervention $(6.8 \%)$. Three patients developed a deep infection immediately after surgery: in two cases this followed infection of a Hickman line and septicaemia while the patient was on chemotherapy.

The same organism, Staphylococcus aureus, was grown from circulating blood during the episode of septicaemia and from aspiration of the prosthesis prior to revision surgery.

In the third case, prosthetic infection followed wound breakdown and septicaemia, again during chemotherapy.

Three patients developed early septic loosening, two with Staphylococcus epidermidis infection, one of whom had been on chemotherapy. The third patient required bladder catheterisation postoperatively and produced a growth of bacteroides. He was also on chemotherapy.

Four late infections developed. In three cases Staphylococcus aureus was the infecting organism. Two of these patients had required further surgery around the knee after the replacement operation. One patient developed a late sinus from which no organism was grown.

\section{DISCUSSION}

Limb salvage surgery can potentially offer patients excellent function and cosmesis with no increased danger, but the method of reconstruction must be durable and not commit the patient to multiple surgical interventions. Patients in this study had a heterogenous group of tumours, thus making assessment of patient survival and local recurrence inappropriate. The performance of the prosthesis, however, can be assessed.

The median age of the patients was only 22 years. They were therefore an unique group to have undergone total knee replacement with a fully constrained prosthesis and massive soft-tissue resection, with the expectation of regaining high levels of activity. The cumulative success rate (when success is defined as an asymptomatic patient with an intact prosthesis) at five and seven years of $72 \%$ and $64 \%$ is similar to that reported for conventional Stanmore prostheses in an older population, where the five- and seven-year results were $69 \%$ and $47 \%$ respectively (Grimer, Karpinski and Edwards 1984).

At five years, 11 of the 30 failures were 'oncological' due to local recurrence of disease or vascular insufficiency secondary to radiotherapy. The incidence of local recurrence following different methods of limb salvage surgery is similar and only slightly higher than that following amputation (Simon et al 1986; Sim, Beauchamp and Chao 1987). If the 11 oncological failures are excluded the success rate of the prosthesis, when defined as an asymptomatic patient who has required no further surgical intervention, at five and seven years, becomes $79 \%$ and $71 \%$.

Loosening has not yet proved to be as large a problem as anticipated for a fully constrained, hinged prosthesis, used in a young active group of patients 
(Fig. 8). The mean age of the six patients who have been revised for aseptic loosening was 15 years (range 12 to 18). All had regained very high levels of physical activity after the original operation.

The low incidence of prosthetic loosening may be attributable to the secure fixation achieved using cement pressurisation techniques in sound diaphyseal bone, and a prosthesis designed with an intramedullary stem, custom made to fit the femoral shaft, leaving an even cement mantle. A prosthesis that allows some axial rotation between the components may decrease the shear stresses further. The early results of prosthetic replacement of the distal femur with prostheses using rotating hinge joints have been encouraging (Eckardt et al 1987).

The incidence of deep infection in this study was $6.8 \%$ compared with $1.7 \%$ reported for 821 conventional knee replacements of various designs (Grogan et al 1986) and $7.8 \%$ for 90 constrained prostheses (Walker and Schurman 1984). The majority of patients in this study were immunosuppressed at the time of surgery and for prolonged periods afterwards. They were therefore vulnerable to primary and secondary infection.

Preventative measures were taken to reduce the risk of infection. Replacement surgery was not undertaken until the biopsy wound had healed; a persistently infected (or badly sited) biopsy wound may preclude limb salvage surgery. Operations were carried out in a clean-air enclosure with vertical laminar air flow, and perioperative antibiotics were used. If possible, central venous lines for chemotherapy were avoided.

The treatment of infection is difficult, function quickly deteriorates and bone stock can be lost rapidly. Revision for infection has been attempted since 1987; prior to this, persistent infection was treated by amputation. We prefer a two-stage exchange. Limb length is temporarily maintained by the use of a cement spacer between the bone ends, and by traction. The cement is loaded with appropriate antibiotics. The short-term results, whilst not as good as the results of revision for loosening or prosthesis fracture, are encouraging and it would appear to offer an attractive alternative to amputation for an infected prosthesis.

The recovery of function following prosthetic replacement of the distal femur is very impressive. Most patients scored well for each parameter of assessment and very few patients considered themselves significantly disabled. The good functional results following revision surgery for loosening have encouraged us to revise for early symptomatic loosening, before much bone stock is lost.

Massive allografts are the most popular alternative to prostheses for limb salvage surgery but are associated with a higher incidence of complications. Mankin, Gebhardt and Tomford (1987a) analysed the results of 56 allografts used around the knee. There was an infection rate of $25 \%$, an allograft fracture rate of $23 \%$ and a nonunion rate of $23 \%$. From the same unit, Lord et al

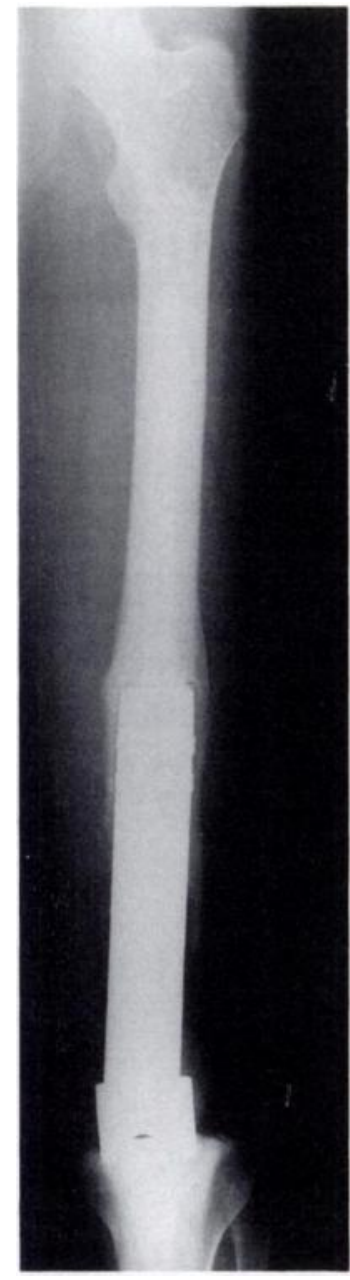

Fig. 8a

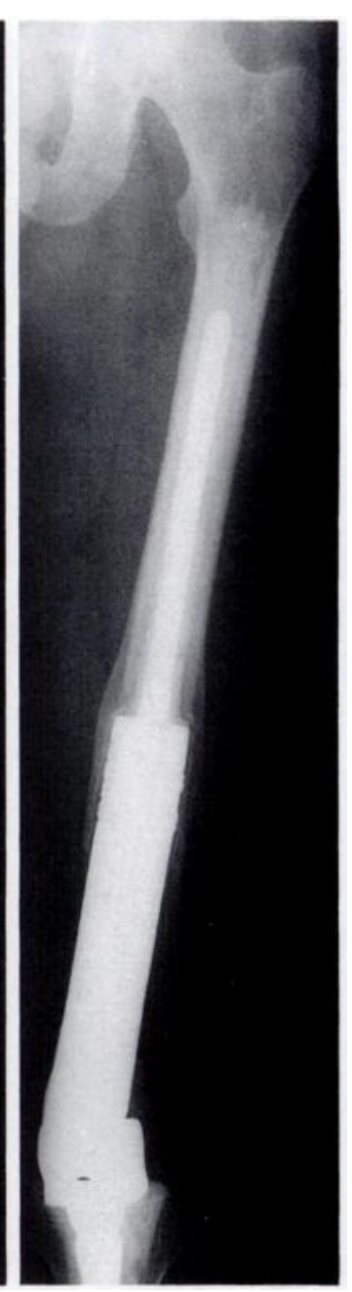

Fig. 8b
Figure 8a - Radiograph taken one year after implantation shows a radiolucent line at the bone-cement interface and a collar of new bone around the shaft. Figure $8 \mathrm{~b}-$ Ten years after implantation there has been no progression of the radiolucent line. The patient remains asymptomatic.

(1988) reported an infection rate of $14.6 \%$ in 82 distal femoral allografts.

The longevity of osteoarticular allografts, as of prostheses, is a matter of concern. When used in weightbearing joints the performance of transplanted articular cartilage is unsatisfactory. The use of allograft/prosthesis combinations has been reported (Jofe et al 1988) but they may carry the risks of both.

The functional results of allograft or prosthetic replacement of the distal femur for tumours are similar. Mankin, Gebhardt and Tomford (1987b) reported good or excellent results in 42 of 55 patients $(76 \%)$, compared to 65 of $71(91 \%)$ in our series, using the same system of assessment. In Mankin's series however, surgery was rarely performed for high grade tumours.

Few studies have compared the functional results of limb salvage surgery with amputation using a standard system of assessment. Otis, Lane and Kroll (1985) have 
demonstrated that the energy cost of walking is $34 \%$ higher for an above-knee amputee than for a patient with a prosthetic replacement of the distal femur. Dubousset and Missenard (1987), using the Musculoskeletal Tumour Society system of assessment, reported eight excellent and three good results in 13 patients following prosthetic replacement of the distal femur for osteosarcoma compared to one excellent and seven good results in 13 patients treated by amputation.

We conclude that prosthetic replacement of the distal femur can satisfy the aim of limb salvage surgery, a good functional result with no more risk to the patient's life than would follow amputation.

No benefits in any form have been received or will be received from a commercial party related directly or indirectly to the subject of this article.

\section{REFERENCES}

Altman DG, Gore SM, Gardner MJ, Pocock SJ. Statistical guidelines for contributors to medical journals. In: Gardner MJ, Altman DG, eds. Statistics with confidence: confidence intervals and statistical guidelines. London: British Medical Journal, 1989:83-100.

Armitage P. Statistical methods in medical research. Oxford and Edinburgh: Blackwell Scientific, 1971.

Bradish CF, Kemp HBS, Scales JT, Wilson JN. Distal femoral replacement by custom-made prostheses. J Bone Joint Surg [Br] 1987; 69-B:276-84.

Burrows HJ, Wilson JN, Scales JT. Excision of tumours of humerus and femur, with restoration by internal prostheses. J Bone Joint Surg [Br] 1975; 57-B:148-59.

Dubousset J, Missenard G. Comparison of functional results of 26 patients with osteogenic sarcoma of the distal femur treated conservatively or by amputation. In: Enneking WF, ed. Limb salvage in musculoskeletal oncology. New York: Churchill Livingstone, 1987:427-9.

Eckardt JJ, Eilber FR, Kabo JM, Mirra JM. Kinematic rotating hinge knee-distal femoral replacement. In: Enneking WF, ed. Limb salvage in musculoskeletal oncology. New York: Churchill Livingstone, 1987, 392-409.

Eilber FR, Morton DL, Eckardt J, Grant T, Weisenburger T. Limb salvage for skeletal and soft tissue sarcomas: multidisciplinary preoperative therapy. Cancer 1984; 53:2579-84.

Eilber F, Giuliano A, Eckardt J, Patterson K, Moseley S, Goodnight J. Adjuvant chemotherapy for osteosarcoma: a randomized prospective trial. J Clin Oncol 1987; 5:21-6.

Enneking WF. Modification of the system for functional evaluation of surgical management of musculoskeletal tumors. In: Enneking WF, ed. Limb salvage in musculoskeletal oncology. New York: Churchill Livingstone, 1987:626-39.
Enneking WF, Spanier SS, Goodman MA. A system for the surgical staging of musculoskeletal sarcoma. Clin Orthop 1980; 153:106-20.

Grimer RJ, Karpinski MRK, Edwards AN. The long-term results of Stanmore total knee replacements. J Bone Joint Surg [Br] 1984; 66-B :55-62.

Grogan TJ, Dorey F, Rollins J, Amstutz HC. Deep sepsis following total knee arthroplasty: ten-year experience at the University of California at Los Angeles Medical Center. J Bone Joint Surg [ Am] $1986 ; 68-A: 226-34$.

Jofe MH, Gebhardt MC, Tomford WW, Mankin HJ. Reconstruction for defects of the proximal part of the femur using allograft arthroplasty. J Bone Joint Surg [ Am] 1988; 70-A :507-16.

Link MP, Goorin AM, Miser AW, et al. The effect of adjuvant chemotherapy on relapse-free survival in patients with osteosarcoma of the extremity. New Engl J Med 1986; 134:1600-6.

Lord CF, Gebhardt MC, Tomford WW, Mankin HJ. Infection in bone allografts. J Bone Joint Surg [Am] 1988; 70-A :369-76.

Machin D, Gardner MJ. Calculating confidence intervals for survival time analyses. $\mathrm{Br}$ Med J 1988; 296:1369-71.

Mankin HJ, Gebhardt MC, Tomford WW. The use of frozen cadaveric allografts in the management of patients with bone tumors of the extremities. Orthop Clin North Am 1987a; 18:275-89.

Mankin HJ, Gebhardt MC, Tomford WW. Use of frozen cadaveric osteoarticular allografts in the treatment of benign and malignant tumors about the knee. In: Enneking WF, ed. Limb salvage in musculoskeletal oncology. New York, etc: Churchill Livingstone, $1987 \mathrm{~b}: 354-64$

Marcove RC, Rosen G. En bloc resections for osteogenic sarcoma. Cancer $1980 ; 45: 3040-4$.

Otis JC, Lane JM, Kroll MA. Energy cost during gait in osteosarcoma patients after resection and knee replacement and after above-theknee amputation. J Bone Joint Surg [Am] 1985; 67-A :606-11.

Rosen G, Marcove RC, Huvos AG, et al. Primary osteogenic sarcoma: eight-year experience with adjuvant chemotherapy. J Cancer Res Clin Oncol 1983; 106:55-67.

Seddon HJ, Scales JT. A polythene substitute for the upper two-thirds of the shaft of the femur. Lancet 1949; ii :795-6.

Sim FH, Beauchamp CP, Chao EYS. Reconstruction of musculoskeletal defects about the knee for tumour. Clin Orthop. 1987; $221: 188-201$.

Simon MA, Aschliman MA, Thomas N, Mankin HJ. Limb salvage treatment versus amputation for osteosarcoma of the distal end of the femur. J Bone Joint Surg [Am] 1986; 68-A:1331-7.

Simon MA, Nachman J. The clinical utility of preoperative therapy for sarcomas. J Bone Joint Surg [Am] 1986; 68-A:1458-63.

Springfield DS, Schmidt R, Graham-Pole J, Marcus RB, Spanier SS, Enneking WF. Surgical treatment of osteosarcoma. J Bone Joint Surg [ Am] 1988; 70-A; 1124-30.

Tew M, Waugh W. Estimating the survival time of knee replacements. J Bone Joint Surg [Br] 1982; 64-B:579-82.

Walker RH, Schurman DJ. Management of infected total knee arthroplasties. Clin Orthop 1984; 186:81-9. 